\title{
Assessment of the implementation of problem- based learning model in Saudi medical colleges: a cross-sectional study
}

This article was published in the following Dove Press journal:

Advances in Medical Education and Practice

\author{
Hassan Al-shehri ${ }^{1}$ \\ Mohamed O'haj' \\ Rayan Elsini ${ }^{3}$ \\ Hatem Alharbi ${ }^{3}$ \\ Mosleh Jabari' \\ Fahad Al-Qashar ${ }^{4}$ \\ Niels Rochow ${ }^{5}$ \\ 'Department of Pediatrics, College \\ of Medicine, Al-Imam Mohammad Ibn \\ Saud Islamic University, Riyadh, Saudi \\ Arabia; ${ }^{2}$ Department of Biochemistry, \\ College of Medicine, University of \\ Bisha, Bisha, Saudi Arabia; ${ }^{3}$ College \\ of Medicine, Al-Imam Mohammad Ibn \\ Saud Islamic University, Riyadh, Saudi \\ Arabia; ${ }^{4}$ Department of Pediatrics, \\ Bahrain Defence Force Hospital, \\ Royal Medical Services, Riffa, Bahrain; \\ ${ }^{5}$ Division of Neonatology, Department \\ of Pediatrics, McMaster University, \\ Hamilton, ON, Canada
}

Background: Problem-based learning (PBL) is a method by which students solve clinical scenarios in a small group discussion. The aim of this study was to assess the implementation of PBL in Saudi Universities.

Methods: This is a cross-sectional study including 151 participants from 16 universities. A questionnaire was distributed to the faculty members through e-mail messages. The questionnaire consisted of 35 questions with 5-point Likert scale arranged in three subscales.

Results: The total mean of PBL implementation score was 2.5 ( $\mathrm{SD}=0.39)$. The scores of the three PBL implementation subscales showed marked variance, with the average score of the subscale "overall PBL experience in my college" being the most highly affected, with an average score of (3.07, SD =0.72), followed by "implementation of PBL model" $(2.36, \mathrm{SD}=0.47)$. The least affected subscale was "preparation for PBL implementation" $(2.13, \mathrm{SD}=0.67)$.

Conclusion: Relatively moderate level of PBL implementation was observed in Saudi Arabia. However, we suggest that more courses should be introduced in order to improve the skills of faculty members and provide a strong infrastructure to implement PBL model in Saudi medical colleges.

Keywords: Saudi Arabia, medical students, problem-based learning, implementation

\section{Introduction}

Problem-based learning (PBL) is a method by which the students solve clinical scenarios in a small group discussion. It is a way of conveying the medical education in an integrated, contextual, self-directed, and student-centered mode of active learning. ${ }^{1}$ Vernon and Blake reported that PBL appears to be a complicated form of a general philosophy of teaching ${ }^{2}$ and is more an educational strategy that helps the brain to learn in a different way. ${ }^{3}$ It has been one of the most important educational innovations for more than four decades. ${ }^{4}$ It was initiated by Howard Barrows in the McMaster University, Hamilton, Ontario, Canada, during the mid-1960s, ${ }^{1}$ and currently there are more than 60 medical schools in the world that have adopted his method, as a whole or in parts. ${ }^{5}$ Howard Barrows had no background in psychologically based education. He and his colleagues submitted the PBL idea as a proposal to the McMaster curriculum for making the medical education more interesting and relevant to the students. ${ }^{6}$

Medical schools have adopted different interpretations and concepts of the PBL curriculum and its approach, ${ }^{6}$ but the results were not significant. ${ }^{2,7,8}$ Also, some studies conducted by Norman and Schmidt ${ }^{9}$ and Elstein et $\mathrm{al}^{10}$ indicate that there is no evidence that one method of teaching can improve the problem-solving skills. However,
Correspondence: Hatem Alharbi

Department of Pediatrics, College of Medicine, Al-Imam Mohammad Ibn Saud Islamic University, 4250 Riyadh | 4285 -7902, Saudi Arabia

Tel +966 I I2037II3

Email hatemalharbi@outlook.com 
the widespread adoption of PBL in medical education proves its validity and value. ${ }^{11}$

PBL involves a progressive theme of provided problems context that has to be built on an integrated prior knowledge ${ }^{11}$ and is based on the principles of the adult learning theory which refers to the motivation of the students, encouragement to set goals, and decision-making skills. ${ }^{12}$ Barrows had identified many objectives, of which that are considered as main objectives of PBL are self-directed learning skills, internal motivation, structuring knowledge and clinical background, and enhancing clinical rationalization. ${ }^{1}$ In addition, the confidence and perception of belonging to the medical schools increased, the exam scores were higher, ${ }^{13}$ and a better understanding of the basic science subjects was observed. ${ }^{14}$ Conductance of PBL for majority of the times can result in desirable outcomes for the undergraduate students, such as critical thinking, communication skills, research skills, ${ }^{4}$ leadership skills, teamwork skills, and others. ${ }^{15}$ It also helps in filling the knowledge gaps and improves previous knowledge and ideas. ${ }^{4}$ Graduates who had undergone PBL were more skillful and efficient in their clinical work, specifically in dealing with the patients, than those who had not undergone PBL. ${ }^{16}$ At the level of the competence, those who had graduated from PBL included curriculum were better than those who came from more traditional curriculum. ${ }^{5}$

The scientific-pedagogical method of conducting a PBL session begins with the triggers from the clinical scenarios which are used to facilitate and guide the students to identify special learning objectives, carry out an independent research, and clarify and interpret findings in the group discussions. ${ }^{17}$ At the beginning of the first session, students will be given a problem included clinical scenario to perform brainstorming, filtering out the unnecessary information and discussing the issues of the case and their suitable solutions. Then, the unanswered inquiries will be the objectives that have to be discussed and explained in the next session, which is called the "reporting session". This session needs some preparations that are navigated by the objectives. ${ }^{18}$

Educationists, medical scientists, and physicians are assigned the responsibility of being the students' supervisors during the sessions. The supervisor's main role is to help the students learn how the scientific investigation process works and deliver the knowledge, attitudes, and skills needed to achieve the goals of the PBL. ${ }^{19}$ Also, from another perspective, Eva et $\mathrm{al}^{20}$ and Neville ${ }^{21}$ presented the PBL tutor's role from a cognitive psychology point of view, which states that the tutor has a critical role in giving a helpful scientific feedback that may help in facilitating the student's learning process.

In the Kingdom of Saudi Arabia, College of Medicine in Al-Qassim University was the first to adopt PBL system in its curriculum in $2003,{ }^{22}$ followed by the rest of the universities in the country. ${ }^{23}$ A study was done to evaluate the PBL course in the College of Medicine, Al-Qassim University, which revealed that the PBL system had a positive impact on improving students' skills. However, most of the students do not agree with the evaluation system but agree that PBL is better than traditional system. ${ }^{4}$ However, another study conducted in the College of Medicine of King Abdulaziz University stated that the PBL system encourages the students to be involved in group discussion. ${ }^{24}$ A study conducted in Taibah University concluded that the majority of their medical academic staff had a good attitude and suitable knowledge in regard to PBL. ${ }^{25}$

Nevertheless, since there is no enough literature emphasizing the adoption of PBL approach in Saudi Arabia, we still do not know if the PBL system is implemented correctly in Saudi Arabia, and this is the aim of the present paper. The specific objectives of this study are:

1. To assess the PBL readiness in Saudi medical colleges.

2. To evaluate the implementation of PBL model.

3. To know overall PBL experience.

\section{Methods}

This cross-sectional study was done by sending an online questionnaire through e-mail messages that were obtained from Saudi universities Websites as well as the attendants of fifth and sixth International Winter Course on PBL in Medical Education in Saudi Arabia. The e-mail messages were sent at 2-week intervals for four times (four reminder messages). The faculty members were invited to participate in the research voluntarily, so completion of the questionnaire was considered an informed consent. The confidentiality and privacy of the reordered responses were kept anonymous and there were no questions that could identify participants. The questionnaire was designed and validated by medical education experts. The institutional review board approval was taken from Al-Imam Muhammad Ibn Saud Islamic University by the research ethics committee.

The questionnaire consisted of two sections. The first section (five questions) comprises the questions on the general information of the participants (academic status, academic background, university, years of teaching, and years of 
experience in PBL). Section two comprises the Likert scale grouped into three subscales based on the PBL implantation. The first subscale is "preparation for PBL implementation (readiness to change)" and contains eight Likert items. The other subscale includes 21 Likert items representing "implementation of PBL model", which contains four Likert items on "training of faculty and students", six items on "tutor skills", seven items regarding "the nature and number of PBL problems in the curriculum", and five items on "assessment of PBL problems". The last subscale measures "overall PBL experience in my college", which includes five Likert items. These three subscales are rated on a five-point Likert scale (1-5) in a categorical manner (strongly disagree, disagree, neutral, agree, strongly agree). Sections 2, 3, and 4 are formatted as a typical five-level Likert scale (strongly agree, agree, neutral, disagree, strongly disagree).

The data were analyzed using SPSS 23 (SPSS Inc., Chicago, IL, USA). We analyzed the data on the subscale scores in two ways. First, descriptive statistics were expressed as mean $\pm \mathrm{SD}$ for the subscales based on the Likert scale (1-5). Second, we used parametric statistics, ie, one-way ANOVA because the scores of the Likert scale were fairly normally distributed.

\section{Results}

We obtained 151 participants from 16 Saudi universities. The majority of the participants were assistant professors $(47.7 \%)$. There were more number of clinicians $(83.6 \%)$ than were basic scientists (16.6\%). About $44.4 \%$ of them had experience in teaching for more than 10 years, while $62.3 \%$ had experience specifically in PBL for $1-5$ years (Table 1 ). Of the 31 universities participated, tutors from 19 universities responded to the survey, with a predominance of Taibah University (16.6\%) followed by Al-Imam Muhammad Ibn Saud Islamic University (14.6\%) and University of Dammam (12.6\%) (Table 2).

The majority of the participants agreed that the PBL system is totally different from the conventional one (87.4\%), and the teacher's role will be more of a facilitator instead of being the only source of knowledge (88.1\%). About $69.5 \%$ have suitable classrooms that facilitate small group discussions, such as in PBL. Rules were modified to allow the students to gather more resources, and not restrict themselves to the classroom desk $(74.8 \%)$. Some of the participants were not prepared to take the risk of reducing their control over students and did not agree with the concept that accepting mistakes is a way of learning (58.2\%). Most of the teachers were prepared to change to a more collaborated
Table I Characteristics of participants

\begin{tabular}{|c|c|}
\hline Academic status & $\%(\mathbf{N})$ \\
\hline Professor & $17.9(27)$ \\
\hline Associate professor & $19.2(29)$ \\
\hline Assistant professor & $47.7(72)$ \\
\hline Lecturer & $7.3(\mathrm{II})$ \\
\hline Teaching assistant & $7.9(12)$ \\
\hline \multicolumn{2}{|l|}{ Academic background } \\
\hline Medical (clinician) & $83.4(126)$ \\
\hline Non-medical (basic scientist) & $16.6(25)$ \\
\hline \multicolumn{2}{|l|}{ Years of teaching experience } \\
\hline None & $2(3)$ \\
\hline $1-5$ years & $35.8(54)$ \\
\hline $6-10$ years & $17.9(27)$ \\
\hline$>10$ years & $44.4(67)$ \\
\hline \multicolumn{2}{|c|}{ Years of experience with PBL } \\
\hline None & $9.3(14)$ \\
\hline $\mathrm{I}-5$ years & $62.3(94)$ \\
\hline $6-10$ years & $17.9(27)$ \\
\hline$>10$ years & $10.6(16)$ \\
\hline \multicolumn{2}{|c|}{$\begin{array}{l}\text { Notes: The assessment method for every PBL session was clear to faculty members } \\
(60.3 \%) \text { and students }(58.9 \%) \text {, and the feedback of tutor to students or groups was } \\
\text { beneficial }(68.9 \%) \text {. The percentage of PBL components involved in each course was } \\
\text { clear for tutors and students }(70.9 \%) \text {, and most of the participants did not know } \\
\text { if the percentage of PBL component in the overall course score is less than to } \\
\text { encourage student interest in PBL sessions (33.1\%) (Table } 4) \text {. } \\
\text { Abbreviation: PBL, problem-based learning. }\end{array}$} \\
\hline
\end{tabular}

Table 2 Name of the universities (\%)

\begin{tabular}{|c|c|}
\hline Al Jouf University - College of Medicine & 0.7 \\
\hline $\begin{array}{l}\text { Al-Imam Muhammad ibn Saud Islamic University - College of } \\
\text { Medicine }\end{array}$ & 14.6 \\
\hline Alfaisal University - College of Medicine & 4.6 \\
\hline Almajmaah University - College of Medicine & 1.3 \\
\hline Batterjee Medical College for Sciences and Technology & 2.6 \\
\hline $\begin{array}{l}\text { King Abdulaziz University - College of Medicine and Allied } \\
\text { Sciences }\end{array}$ & 11.3 \\
\hline King Faisal University, Al Khobar - College of Medicine & 1.3 \\
\hline $\begin{array}{l}\text { King Khalid University - College of Medicine and Health } \\
\text { Sciences }\end{array}$ & 0.7 \\
\hline $\begin{array}{l}\text { King Saud Bin Abdulaziz University for Health Sciences, } \\
\text { Jeddah, College of Medicine }\end{array}$ & 0.7 \\
\hline King Saud University, Riyadh - College of Medicine & 6.6 \\
\hline Najran University - College of Medicine & 4 \\
\hline Northern Borders University - College of Medicine & 2 \\
\hline Prince Sattam bin Abdulaziz University - College of Medicine & 0.7 \\
\hline Sulaiman Alrajhi - College of Medicine & 0.7 \\
\hline Taibah University - College of Medicine & 16.6 \\
\hline Taif University - College of Medicine & 6.6 \\
\hline Umm Al-Qura University - Faculty of Medicine & 9.9 \\
\hline University of Dammam - College of Medicine & 12.6 \\
\hline University of Bisha - College of Medicine & 2.6 \\
\hline Total & 100 \\
\hline
\end{tabular}

interdisciplinary approach, rather than being a one-man show subject expert (65.5\%) (Table 3).

All the faculties and students did not have adequate training in PBL (44.4\%), but was sufficient enough to make 
Table 3 Frequency distribution of "preparation for PBL implementation"

\begin{tabular}{|c|c|c|c|c|c|}
\hline Preparation for PBL implementation items (readiness changes) & $\begin{array}{l}\text { Strongly } \\
\text { disagree, } \\
\%(\mathbf{N})\end{array}$ & $\begin{array}{l}\text { Disagree, } \\
\%(\mathbf{N})\end{array}$ & $\begin{array}{l}\text { Not } \\
\text { know, } \\
\%(N)\end{array}$ & $\begin{array}{l}\text { Agree, } \\
\%(\mathbf{N})\end{array}$ & $\begin{array}{l}\text { Strongly } \\
\text { agree, } \\
\%(\mathbf{N})\end{array}$ \\
\hline $\begin{array}{l}\text { Everyone in my school agreed that using PBL is totally different than the } \\
\text { conventional method }\end{array}$ & 0 & $7.9(12)$ & $4.6(7)$ & $50.3(76)$ & $37.1(56)$ \\
\hline $\begin{array}{l}\text { Faculty and students believed that the role of teacher will change to a facilitator of } \\
\text { learning, and not the only source of knowledge }\end{array}$ & 0 & $6(9)$ & $6(9)$ & $46.4(70)$ & $41.7(63)$ \\
\hline $\begin{array}{l}\text { Classrooms were designed and facilitated in a way to suit the flexibility of small } \\
\text { group discussions of PBL }\end{array}$ & 0 & $27.8(42)$ & $2.6(4)$ & $35.1(53)$ & $34.4(52)$ \\
\hline $\begin{array}{l}\text { Rules were modified to allow students gather resources, not only waiting in the } \\
\text { classroom desk }\end{array}$ & 0 & $13.2(20)$ & $11.9(18)$ & $43(56)$ & $31.8(48)$ \\
\hline $\begin{array}{l}\text { Integration, vertically and horizontally between different disciplines, was made in } \\
\text { curriculum of PBL to overcome the subject compartment and boundaries }\end{array}$ & 0 & $13.9(2 \mid)$ & $9.9(15)$ & $51(77)$ & $25.2(38)$ \\
\hline $\begin{array}{l}\text { Teachers and administrators were prepared to take the risk of reducing their } \\
\text { control over students and accepted mistakes as cause of learning }\end{array}$ & 0 & $25.2(38)$ & $16.6(25)$ & $45(68)$ & $13.2(20)$ \\
\hline $\begin{array}{l}\text { Teachers were prepared to move to a more interdisciplinary collaboration than } \\
\text { one-man-show subject expert }\end{array}$ & 0 & $19.9(30)$ & $14.6(22)$ & $39.7(60)$ & $25.8(39)$ \\
\hline $\begin{array}{l}\text { Continuous development of PBL curriculum and rules were considered in designing } \\
\text { and implementing the PBL model }\end{array}$ & 0 & I5.2(23) & 11.9 (18) & 51 (77) & $21.9(33)$ \\
\hline
\end{tabular}

Abbreviation: PBL, problem-based learning.

them understand what is PBL (54.9\%) and stimulate the interest in student-centered learning among both faculty and students (59\%).

The tutors were skilled at introducing the problems (67.5\%), directing students' discussions toward the objectives (76.8\%), stimulating critical thinking during their discussions $(71.5 \%)$, providing information only when necessary (65.6\%), creating a competitive environment where all students were encouraged to participate in discussions (76.8\%), taking notes to provide the feedback for individuals and the group (68.3\%).

About $67.6 \%$ of the participants "agree and strongly agree" that several PBL tutorials be added to the conventional curriculum. Well-structured PBL problems were incorporated into the renewed curriculum (45.3\%). There were an adequate number of problems for each course $(64.9 \%)$ and across the curriculum as a whole (59.6\%). They were well distributed between the basic sciences and clinical courses $(60.3 \%)$, and the time given for each problem was quite sufficient (76.2\%).

According to the faculty members' experience with PBL, their perception about PBL was that it was appropriate (44.4\%), and their colleges were ready to implement PBL model (49\%). Obstacles faced during the implementation of PBL model were not due to faculty (40.4\%) or students' resistance toward changing into the PBL model (49.7\%). Moreover, $76.2 \%$ of the tutors did not prefer going back to the conventional lecture method (Table 5).
The total mean of PBL implementation score was 2.5 (SD $=0.39$ ). The score of the three PBL implementation subscales showed marked variance; the average score of the subscale "overall PBL experience in my college" was the most highly affected, with an average score of $(3.07, \mathrm{SD}=0.72)$. This was followed by subscale "implementation of PBL model" (2.36, $\mathrm{SD}=0.47)$, and the least affected subscale was "preparation for PBL implementation" (2.13, SD =0.67) (Table 6).

Regarding Saudi universities, the overall score of PBL implementation and its subscales were statistically significant $(P<0.05)$ with the exception of "overall PBL experience in my college" $(P>0.05)$ (Table 6).

\section{Discussion}

In this study, we evaluated the "implementation of PBL" model in Saudi medical colleges. Overall, the study revealed a moderate level (50\%) of PBL implementation rate in Saudi Arabia.

In a recent review of the literature, a study that assessed the learning among undergraduate medical students in schools with PBL curriculum in Saudi Arabia was done by $\mathrm{Meo}^{26}$, which stressed the fact that students undergoing PBL possessed significantly high knowledge and skills compared with those who belonged to traditional styles of medical schools. Furthermore, PBL has a good impact on the students, which was proved by a comparison between pre-PBL and post-PBL sessions. ${ }^{26}$ Also, significant improvement in overall performance was observed. ${ }^{12}$ In addition, students 
Table 4 Frequency distribution of "implementation of PBL" model

\begin{tabular}{|c|c|c|c|c|c|}
\hline Implementation of PBL model items & $\begin{array}{l}\text { Strongly } \\
\text { disagree, } \\
\%(\mathbf{N})\end{array}$ & $\begin{array}{l}\text { Disagree, } \\
\%(\mathbf{N})\end{array}$ & $\begin{array}{l}\text { Not } \\
\text { know, } \\
\%(N)\end{array}$ & $\begin{array}{l}\text { Agree, } \\
\%(\mathbf{N})\end{array}$ & $\begin{array}{l}\text { Strongly } \\
\text { agree, } \\
\%(\mathbf{N})\end{array}$ \\
\hline \multicolumn{6}{|l|}{ Training of faculty and students } \\
\hline All faculty and students had sufficient training on PBL & 0 & $44.4(67)$ & $15.9(24)$ & $34.4(52)$ & $5.3(8)$ \\
\hline The PBL training was fair enough to make trainees understand what is $P B L$ & 0 & $23.8(36)$ & $21.2(32)$ & $45(68)$ & $9.9(15)$ \\
\hline $\begin{array}{l}\text { The PBL training was fair enough to stimulate the interest in student-centered } \\
\text { learning among both faculty and students }\end{array}$ & 0 & $26.5(40)$ & $14.6(22)$ & $44.4(67)$ & $14.6(22)$ \\
\hline All faculty and students were ready for the challenge of adopting PBL model & 0 & $34.4(52)$ & $21.9(33)$ & $33.1(50)$ & $10.6(16)$ \\
\hline \multicolumn{6}{|l|}{ Tutor skills } \\
\hline Good introduction of the specific problem & 0 & $11.9(18)$ & $20.5(31)$ & $53.6(8 I)$ & $13.9(2 \mid)$ \\
\hline Directed student discussion groups to concentrate on learning objectives & 0 & $9.3(14)$ & $13.9(2 \mid)$ & $60.9(92)$ & $15.9(24)$ \\
\hline Stimulate critical thinking during group discussions & 0 & $12.6(19)$ & $51.9(24)$ & $5 I(77)$ & $20.5(31)$ \\
\hline Ready to provide information only when necessary & 0 & $17.9(27)$ & $16.6(25)$ & $49.7(75)$ & $15.9(24)$ \\
\hline $\begin{array}{l}\text { Help students to participate in group discussion and creation of a competitive } \\
\text { environment }\end{array}$ & 0 & $8.6(13)$ & $14.6(22)$ & $5 \mathrm{I}(77)$ & $25.8(39)$ \\
\hline Take notes and provide feedback for individuals and the group & 0 & $9.3(14)$ & $22.5(34)$ & $51.7(78)$ & $16.6(25)$ \\
\hline \multicolumn{6}{|l|}{ Nature and number of PBL problems in the curriculum } \\
\hline Only some PBL tutorials were added to the conventional curriculum & 0 & $44.4(67)$ & $23.2(35)$ & $23.8(36)$ & $8.6(13)$ \\
\hline No well-structured PBL problems were incorporated in the renewed curriculum & 0 & $45.3(82)$ & $17.2(26)$ & $21.9(33)$ & $6.6(10)$ \\
\hline The number of problems per each course was adequate. & 0 & $14.6(22)$ & $20.5(31)$ & $53(80)$ & $11.9(18)$ \\
\hline The number of problems across the curriculum was adequate & 0 & $14.6(22)$ & $25.8(39)$ & $46.4(70)$ & $13.2(20)$ \\
\hline Problems were properly distributed between the basic science and clinical courses & 0 & $21.2(32)$ & $18.5(28)$ & $45.7(69)$ & $14.6(22)$ \\
\hline The time allocated for each problem was quite sufficient & 0 & $12.6(19)$ & $11.3(17)$ & $53(80)$ & $23.2(35)$ \\
\hline \multicolumn{6}{|l|}{ Assessment of PBL problems } \\
\hline Assessment method for each PBL session is clear to faculty members & 0 & $26.5(40)$ & $13.2(20)$ & $44.4(67)$ & $15.9(24)$ \\
\hline Assessment method for each PBL session is clear for students & 0 & $19.2(29)$ & $21.9(33)$ & $43.7(66)$ & $15.2(23)$ \\
\hline The feedback of tutor to students/groups is quite useful & 0 & $11.3(17)$ & $19.9(30)$ & $43.7(66)$ & $25.2(38)$ \\
\hline The percentage of PBL components of the overall course score is clear & 0 & $9.3(14)$ & $19.9(30)$ & $51(77)$ & $19.9(30)$ \\
\hline $\begin{array}{l}\text { The percentage of PBL component in the overall course score is less than that } \\
\text { required to encourage student interest in PBL sessions }\end{array}$ & 0 & $28.5(43)$ & $33.1(50)$ & $29.1(44)$ & $9.3(14)$ \\
\hline
\end{tabular}

Abbreviation: PBL, problem-based learning.

Table 5 Frequency distribution of "overall PBL experience in my college"

\begin{tabular}{|c|c|c|c|c|c|}
\hline Overall PBL experience in my college & $\begin{array}{l}\text { Strongly } \\
\text { disagree, } \\
\%(\mathbf{N})\end{array}$ & $\begin{array}{l}\text { Disagree, } \\
\%(\mathbf{N})\end{array}$ & $\begin{array}{l}\text { Not } \\
\text { know, } \\
\%(N)\end{array}$ & $\begin{array}{l}\text { Agree, } \\
\%(\mathbf{N})\end{array}$ & $\begin{array}{l}\text { Strongly } \\
\text { agree, } \\
\% \text { (N) }\end{array}$ \\
\hline $\begin{array}{l}\text { I think my college was not ready enough when they started implementing the PBL } \\
\text { model }\end{array}$ & 0 & $49(74)$ & $13.9(2 \mid)$ & $22.5(34)$ & $14.6(22)$ \\
\hline Faculty perception about PBL was inappropriate & 0 & $44.4(67)$ & $15.2(23)$ & $27.8(42)$ & $12.6(19)$ \\
\hline Student insight regarding PBL was impartial & 0 & $29.8(45)$ & $28.5(43)$ & $30.5(46)$ & $11.3(17)$ \\
\hline $\begin{array}{l}\text { Faculty resistance for the change to } \mathrm{PBL} \text { was behind the pitfalls in implementing the } \\
\mathrm{PBL} \text { model }\end{array}$ & 0 & $40.4(6 I)$ & $23.8(36)$ & $25.8(39)$ & $9.9(15)$ \\
\hline $\begin{array}{l}\text { Student resistance to change to PBL was behind the pitfalls in implementing the PBL } \\
\text { model }\end{array}$ & 0 & $49.7(75)$ & $27.8(42)$ & $17.9(27)$ & $4.6(7)$ \\
\hline $\begin{array}{l}\text { I think it is better to go back to the conventional lecture method than adopting the } \\
\text { PBL model }\end{array}$ & 0 & $76.2(115)$ & $8.6(13)$ & $4(6)$ & II.3 (I7) \\
\hline
\end{tabular}

Abbreviation: PBL, problem-based learning.

who followed PBL teaching model achieved better academic performance than those following the traditional (lecturebased learning [LBL]) style of education. ${ }^{12}$ Fortunately, this comes with an agreement from faculty perspective where $76.2 \%$ agree that PBL is better than conventional lectures.
The tutor skills in this study achieved a mean score of 2.22. This comes in contrast with Moutasem Aboonq's study at the College of Medicine, Taibah University, which revealed that high percentage of faculty have a good knowledge and favorable attitude toward PBL. ${ }^{25}$ These contrasting data could 
Table 6 Difference and significance of PBL implementation subscales among Saudi medical colleges

\begin{tabular}{|c|c|c|c|c|c|}
\hline PBL implementation subscales & Mean (SD $\left.{ }^{\mathrm{a}}\right)$ & Mean (SD $)$ & Possible range & Possible range & $P$-value \\
\hline $\begin{array}{l}\text { Preparation for PBL implementation (readiness changes) (eight } \\
\text { items) }\end{array}$ & $2.13(0.67)$ & $17.05(5.36)$ & $8-40$ & $8-40$ & 0.001 \\
\hline \multicolumn{6}{|l|}{ Implementation of PBL model ( 2 I items) } \\
\hline - Training of faculty and students (four items) & $2.36(0.47)$ & $54.97(10.44)$ & $21-105$ & $21-105$ & 0.008 \\
\hline - Tutor skills (six items) & $2.73(0.83)$ & $10.91(3.302)$ & $4-20$ & $4-20$ & 0.005 \\
\hline - The nature and number of PBL problems in the curriculum & $2.22(0.68)$ & $13.34(4.06)$ & $6-30$ & $6-30$ & 0.016 \\
\hline (seven items) & $2.56(0.47)$ & $18.12(3.32)$ & $7-35$ & $7-35$ & 0.039 \\
\hline - Assessment of PBL problems (five items) & $2.5 I(0.47)$ & $12.59(2.37)$ & $5-25$ & $5-25$ & 0.442 \\
\hline Overall PBL experience in my college (five items) & $3.07(0.72)$ & $15.35(3.59)$ & $5-25$ & $5-25$ & 0.225 \\
\hline Overall score ( 35 items) & $2.5(0.39)$ & 87.37 (13.59) & $35-175$ & $35-175$ & 0.001 \\
\hline
\end{tabular}

Note: ${ }^{a}$ Based on average of Likert scale response options: I-5; bbased on sum of the Likert scale response options: $1-5$.

Abbreviation: PBL, problem-based learning.

be attributed to the number of universities involved in this study, including Taibah University, or due to the time difference between the studies. Regarding the tutors' skills, most of the tutors provided feedback to the students $(68.3 \%)$, which were beneficial (68.9\%). However, according to a study conducted in the medical college of Al-Qassim University, about $67.4 \%$ of the students did not receive beneficial feedback from their tutors. A total of $44.2 \%$ claimed that the tutors did not mention the objectives clearly from the beginning, and they did not clarify as to what they expected from the students. ${ }^{4}$ This means that there was no clear level of communication between the tutor and the student.

About $43.7 \%$ of the participants think that both faculty and students were ready for the challenge of adopting the PBL model, but some (37.1\%) stated that their colleges were not well prepared when the PBL model was being implemented; this might have led to different obstacles which are mentioned in a study done by Bashir Hamad, ${ }^{22}$ such as insufficient resources (eg, library, laboratories, clinical faculty); English language; lack of clear instructions and agreement on PBL format, and lack of satisfaction in the system; untrained tutors; lack of time (especially for selfdirected learning); student problems (preparation before the sessions, language, no willingness for self-learning, and dependence on the lectures); problem design; evaluation of PBL problems and students.

For future improvement in PBL implementation, efforts should be directed to raise tutor skills and prepare a good environment to implement the PBL teaching method efficiently (mean $<2.5)$.

\section{Limitations}

Since the sample included in this study is low, another study with a larger sample is recommended.

\section{Conclusion}

The overall mean of PBL implementation score in Saudi medical colleges was 2.5. However, efforts should be taken in raising tutor skills and providing enough infrastructure to implement PBL teaching method efficiently.

\section{Disclosure}

The authors report no conflicts of interest in this work.

\section{References}

1. Barrows HS. A taxonomy of problem-based learning methods. Med Educ. 1986;20(6):481-486.

2. Vernon DT, Blake RL. Does problem-based learning work? A metaanalysis of evaluative research. Acad Med. 1993;68(7):550-563.

3. Walton HJ, Matthews MB. Essentials of problem-based learning. Med Educ. 1989;23(6):542-558.

4. Shamsan B, Syed AT. Evaluation of problem based learning course at college of medicine, Qassim University, Saudi Arabia. Int J Health Sci. 2009;3(2):249-258.

5. Neville AJ. Problem-based learning and medical education forty years on. A review of its effects on knowledge and clinical performance. Med Princ Pract. 2009;18(1):1-9.

6. Barrows HS. Problem-based Learning Applied to Medical Education. Southern Illinois University School of Medicine; 2000:147.

7. Berkson L. Problem-based learning: have the expectations been met? Acad Med. 1993;68(10 Suppl):S79-S88.

8. Albanese MA, Mitchell S. Problem-based learning: a review of literature on its outcomes and implementation issues. Acad Med. 1993;68(1):52-81.

9. Norman GR, Schmidt HG. The psychological basis of problem-based learning: a review of the evidence. Acad Med. 1992;67(9):557-565.

10. Elstein, Arthur S, Shulman LS, Sprafka SA. Medical Problem Solving: An Analysis of Clinical ReasoningScience, Technology, \& Human Values 1978 06/01. Science, Technology, \& Human Values 1978 06/01. Cambridge, MA: Harvard University Press; 1978:50-51.

11. Maudsley G. Do we all mean the same thing by "problem-based learning"? A review of the concepts and a formulation of the ground rules. Acad Med. 1999;74(2):178-185.

12. Preeti B, Ashish A, Shriram G, Learning PB. Problem Based Learning (PBL) - An Effective Approach to Improve Learning Outcomes in Medical Teaching. J Clin Diagn Res. 2013;7(12):2896-2897.

13. Jones R, Higgs R, de Angelis C, Prideaux D. Changing face of medical curricula. Lancet. 2001;357(9257):699-703.

14. Dolmans D, Schmidt H. The advantages of problem-based curricula. Postgrad Med J. 1996;72(851):535-538. 
15. Dixit H, Vaidya S, Pradhan B. PBL implementation of Kathmandu University Curriculum - Is It Quo Vadis? JNMA J Nepal Med Assoc. 2013;52(192):652-658.

16. Richards R, Fülöp T, Bannerman J, et al. Innovative schools for health personnel: report on ten schools belonging to the Network of Community-Oriented Educational Institutions for Health Sciences. Geneva: WHO; 1987.

17. Wood DF. ABC of learning and teaching in medicine: problem based learning. BMJ. 2003;326(7384):328-330.

18. Brock Enger K, Brenenson S, Lenn K, et al. Problem-based learning: evolving strategies and conversations for library instruction. Ref Serv Rev. 2002;30(4):355-358.

19. Tamim HM, Al-Kadri HM, Zamakhshary MF, et al. Research as a requirement in a problem-based learning medical curriculum in Saudi Arabia. Saudi Med J. 2012;33(11):1241-1243.

20. Eva KW, Neville AJ, Norman GR. Exploring the etiology of content specificity: factors influencing analogic transfer and problem solving. Acad Med. 1998;73(10 Supp1):S1-S5.

21. Neville AJ. The problem-based learning tutor: Teacher? Facilitator? Evaluator? Med Teach. 1999;21(4):393-401.
22. Al-Damegh $\mathrm{S}$. The challenges of implementing a new curriculum at $\mathrm{Al}$ Qaseem College of Medicine, Saudi Arabia: a study on the initial implementation problems. Available from: http://www.academia.edu/776995/ The_challenges_of_implementing_a_new_curriculum_at_Al_Qaseem_College_of_Medicine_Saudi_Arabia_A_Study_on_the_Initial_Implementation_Problems. Accessed January 18, 2018.

23. Telmesani A, Zaini RG, Ghazi HO. Medical education in Saudi Arabia: a review of recent developments and future challenges. East Mediterr Health J. 2011;17(8):703-707.

24. Shawwa LAA, Deek BSE, Haggi SK, Habshi AME. Self directed learning (problem based approach) in the integrated curriculum of King Abdulaziz University, perception and practice of medical students: a comparative cross-sectional sudy. Res J Med Sci. 2013;7(1):20-24.

25. Aboonq M. Perception of the faculty regarding problem-based learning as an educational approach in Northwestern Saudi Arabia. Saudi MedJ. 2015;36(11):1329-1335.

26. Meo SA. Evaluating learning among undergraduate medical students in schools with traditional and problem-based curricula. Adv Physiol Educ. 2013;3722(3):249-253.
Advances in Medical Education and Practice

\section{Publish your work in this journal}

Advances in Medical Education and Practice is an international, peerreviewed, open access journal that aims to present and publish research on Medical Education covering medical, dental, nursing and allied health care professional education. The journal covers undergraduate education, postgraduate training and continuing medical education

\section{Dovepress}

including emerging trends and innovative models linking education, research, and health care services. The manuscript management system is completely online and includes a very quick and fair peer-review system. Visit http://www.dovepress.com/testimonials.php to read real quotes from published authors.

Submit your manuscript here: http://www.dovepress.com/advances-in-medical-education-and-practice-journal 